\title{
Removal of antibiotic resistance genes in two tertiary level municipal wastewater treatment plants
}

McConnell, Mandy M.; Hansen, Lisbeth Truelstrup; Jamieson, Rob C.; Neudorf, Kara D.; Yost, Christopher K.; Tong, Anthony

Published in:

Science of the Total Environment

Link to article, DOI:

10.1016/j.scitotenv.2018.06.212

Publication date:

2018

Document Version

Peer reviewed version

Link back to DTU Orbit

Citation (APA):

McConnell, M. M., Hansen, L. T., Jamieson, R. C., Neudorf, K. D., Yost, C. K., \& Tong, A. (2018). Removal of antibiotic resistance genes in two tertiary level municipal wastewater treatment plants. Science of the Total Environment, 643, 292-300. https://doi.org/10.1016/j.scitotenv.2018.06.212

\section{General rights}

Copyright and moral rights for the publications made accessible in the public portal are retained by the authors and/or other copyright owners and it is a condition of accessing publications that users recognise and abide by the legal requirements associated with these rights.

- Users may download and print one copy of any publication from the public portal for the purpose of private study or research.

- You may not further distribute the material or use it for any profit-making activity or commercial gain

- You may freely distribute the URL identifying the publication in the public portal 


\section{Removal of Antibiotic Resistance Genes in Two Tertiary 2 Level Municipal Wastewater Treatment Plants}

3

4

5 Mandy M. McConnell ${ }^{\mathrm{a}}$, Lisbeth Truelstrup Hansen ${ }^{\mathrm{b} * 1}$, Rob C. Jamieson ${ }^{\mathrm{a}}$, Kara D.

6 Neudorf $^{\mathrm{b}}$, Christopher K. Yost ${ }^{\mathrm{c}}$, Anthony Tong ${ }^{\mathrm{d}}$.

$8{ }^{\text {a }}$ Department of Civil and Resources Engineering, Dalhousie University, 1360 Barrington

9 Street, Halifax B3H 4R2, Canada

$10{ }^{\mathrm{b}}$ Department of Process Engineering and Applied Science, Dalhousie University, 1360

11 Barrington Street, Halifax B3H 4R2, Canada

$12{ }^{\mathrm{c}}$ Department of Biology, University of Regina, 3737 Wascana Parkway, Regina, SK S4S

13 0A2, Canada

$14{ }^{\mathrm{d}}$ Department of Chemistry, Acadia University, 6 University Avenue, Wolfville, Nova

15 Scotia, Canada B4P 2R6

16 *Corresponding author at: National Food Institute, Technical University of Denmark,

17 Denmark.

18 E-mail address: litr@food.dtu.dk (L. Truelstrup Hansen).

$19{ }^{1}$ Present address: National Food Institute, Technical University of Denmark, DK-2800

20 Kongens Lyngby, Denmark. 


\section{Abstract}

23 Raw wastewater can contain high levels of antibiotic resistance genes (ARGs), making

24 municipal wastewater treatment plants (WWTPs) critical for the control of the release of

25 ARGs into the environment. The objective of this study was to investigate how individual

26 treatment steps in two tertiary WWTPs affected the removal (copies/mL) and relative

27 abundance of ARGs (copies/copies 16S rRNA genes). Nine ARG markers, representing

28 resistance to commonly used antibiotics, as well as one integron gene (intl1) to assess

29 ARG mobility potential, were quantified using quantitative real-time PCR (qPCR). Both

30 WWTPs met provincial effluent regulations for removal of carbonaceous oxygen demand

$31\left(\mathrm{CBOD}_{5}\right)$ and total suspended solids. Eight of the ten ARG markers (intl1, sul1, sul2,

32 tet( $(\mathrm{O})$, ermB, bla $a_{\mathrm{CTX}-\mathrm{M}}$, bla $\left.a_{\mathrm{TEM}}, q n r \mathrm{~S}\right)$ were detected in all samples. In contrast, mecA was

33 detected intermittently and vanA remained below the detection limit in all samples. The

34 total ARG marker abundances decreased by $\log 1.77(\mathrm{p}<0.05)$ in the plant using an

35 aerated lagoon (AL), and by 2.69 logs $(\mathrm{p}<0.05)$ through treatment in the plant employing

36 a biological nutrient removal (BNR) system. The BNR and secondary clarifier steps in

37 both plants afforded the most removal of ARGs. The relative abundance of ARGs

38 remained unchanged at the AL plant and showed a decreasing trend at the BNR plant.

39 Levels of $\mathrm{CBOD}_{5}$, nitrate and the human Bacteroides fecal marker correlated with ARG

40 concentrations, suggesting these variables may be useful in predicting ARG removal. In

41 conclusion, the effluent coming from the WWTPs contained eight of the studied ARG

42 markers in concentrations ranging from 0.01 to $3.6 \log$ copies $/ \mathrm{mL}$, indicating their release

43 into the environment, however, the relative abundance of ARGs was not enriched during

44 treatment in the two WWTPs. 


\section{$45 \quad 1$ Introduction}

46 The overuse and misuse of antibiotics in medical and agricultural settings have

47 resulted in their continuous release into the environment, which has contributed to the

48 development of antibiotic resistant bacteria due to the selective pressure of the antibiotic

49 residues (Davies and Davies, 2010). The efficacy of antibiotics may be reduced if

50 antibiotic resistant genes (ARGs) are transferred to dangerous pathogens. Even in the

51 absence of selective pressures, ARGs can persist in the environment and have been found

52 in naturally occurring bacteria (Allen et al., 2010; Martinez, 2009; Tamminen et al.,

53 2011). However, environments that are influenced by anthropogenic activities show

54 higher concentrations of antibiotic resistant bacteria and ARGs (Allen et al., 2010;

55 Pruden et al., 2006). Internationally, ARGs and antibiotic residues have now been

56 recognized as emerging environmental pollutants (Pruden et al., 2006; Sanderson et al.,

57 2016).

58 The effluent from wastewater treatment plants (WWTPs) is thought to be a major

59 anthropogenic source for the release of antibiotic residues, antibiotic resistant bacteria,

60 and ARGs into the environment (Czekalski et al., 2012; Munir et al., 2011; Rizzo et al.

61 2013). Although WWTPs are designed to remove carbonaceous materials, nutrients and

62 pathogenic bacteria, they are not specifically designed to remove antibiotics and

63 resistance elements (Barancheshme and Munir, 2018). Many ARGs are located on

64 integrons, transposons, or plasmids, which allow mobilization and transfer to other

65 bacteria (Allen et al., 2010). Biological wastewater treatment, due to the presence of large

66 microbial communities, may create an ideal environment for selection and/or horizontal

67 gene transfer of ARGs. Contributing factors include the close proximity of bacteria 
originating from multiple sources, as well as a selective, nutrient-rich environment containing both antibiotics and heavy metals (Baquero et al., 2008; Davies and Davies, 2010; Levy and Marshall, 2004; Rizzo et al., 2013). Therefore, due to the risk of ARG enrichment during the treatment process and subsequent discharge into the environment, understanding wastewater related reservoirs is crucial to assessing the risk of antibiotic resistance transfer in the natural environment.

Antibiotics, antibiotic resistant bacteria and ARGs can be affected differently within WWTPs due to variations in the operations of the plant (Batt et al., 2007; Rizzo et al., 2013; Barancheshme and Munir, 2018). Many previous studies have primarily focused on influent and effluent samples, without analyzing the impact of individual steps in wastewater treatment processes (Laht et al., 2014; Narciso-da-rocha et al., 2014; Rodriguez-Mozaz et al., 2015). In order to better design plants to increase removal of resistance determinants and decrease their subsequent release into the environment, it is important to assess the effect of each step in the treatment process. This has therefore been the focus of more recent studies (e.g., Di Cesare et al., 2016, Lee et al., 2017). In Canada, WWTP effluent quality is monitored through measurement of parameters such as total suspended solids (TSS), carbonaceous biological oxygen demand (CBOD $)$, or nutrient levels (Wastewater Systems Effluent Regulations, Environment Canada, 2015). Currently, neither antibiotics nor resistance elements are monitored for regulatory compliance purposes. Past studies have found significant correlations between the removal of nutrients and organic matter throughout treatment, and ARG concentrations (Nõlvak et al., 2013; Novo and Manaia, 2010). Therefore, examining these correlations may aid in finding potential proxies for monitoring ARG levels in treated wastewater. 
The objective of this study was to examine how the individual treatment steps in

92 two tertiary WWTPs, using different biological treatment operations, affected the

93 abundance of nine ARGs, and one genetic indicator of mobility potential of ARG

94 cassettes (intl1 integrase). A collection of water quality parameters (Escherichia coli,

95 ammonia, phosphorus, $\mathrm{CBOD}_{5}, \mathrm{HF183}$ human Bacteroides marker, bacterial 16S rRNA

96 gene copy numbers, etc.) and presence of selected antibiotics were also assessed in order

97 to examine their potential relationships to ARG abundances.

98

$99 \quad 2$ Materials and Methods

100

2.1 Treatment plants and sample collection sites

101

Samples were collected from two different types of tertiary WWTPs in Atlantic

102 Canada; an aerated lagoon (AL plant) system, and a biological nutrient removal (BNR)

103 system (BNR plant). The AL plant was sampled four times (July 7 and 28, and August

104 18, 2015, and February 23, 2016). The BNR plant was sampled on July 12, 2016 and

105 July 18, 2017.

106

107

\subsubsection{AL Plant}

108

The AL plant discharges approximately $3.8 \times 10^{6}$ L/day of treated effluent into a river. The WWTP services around 600-800 customer connections including a Canadian

110 Forces airbase, which contains a small hospital unit. There would also be several small

111 commercial operations in the sewershed. Treatment steps include screening, two

112 mechanically aerated lagoons (no recycling), two clarifiers, sand filtration, and ultra 
113 violet light (UV) disinfection. The hydraulic retention time in the lagoons ranges between

11418 and 24 hours (personal communications, plant operator), the organic loading rate to

115 the lagoons is $0.12 \mathrm{~kg} \mathrm{CBOD} 5 / \mathrm{m}^{2} / \mathrm{d}$, and the mixed liquor suspended solids (MLSS) is

116 approximately $300 \mathrm{mg} / \mathrm{L}$. The surface overflow rate of the clarifiers is $14 \mathrm{~m} / \mathrm{d}$. The UV

117 system is a Trojan 3000 PTP (Trojan Technologies, London, ON, Canada) with a design

$118 \mathrm{UV}$ dose of $50 \mathrm{~mJ} / \mathrm{cm}^{2}$. The plant is designed to produce effluent with a maximum of 5

$119 \mathrm{mg} / \mathrm{L}$ for $\mathrm{CBOD}_{5}$ and $5 \mathrm{mg} / \mathrm{L}$ for TSS. Duplicate water samples were collected in pre-

120 sterilized 1 L Nalgene collection bottles (Thermo Fisher Scientific, Waltham, MA,

121 United States) after the screen (A) [referred to as the influent as it was the first accessible

122 sampling site], after the mechanically aerated lagoons where water from the two lagoons

123 was mixed (B), after the clarifiers where the effluent from two clarifiers was mixed (C),

124 after sand filtration (D) and after UV disinfection (E) as shown in Figure 1A. Water

125 samples were kept on ice while being transported back to the laboratory at Dalhousie

126 University in Halifax, NS (a distance of approximately $150 \mathrm{~km}$ ), stored at $4^{\circ} \mathrm{C}$ overnight

127 and processed the following morning.

128

\subsubsection{BNR Plant}

The BNR plant services approximately 13,000 people in an urban area, including

131 a local hospital, and light commercial and industrial operations. The effluent discharge of

132 approximately $11.4 \times 10^{6} \mathrm{~L} /$ day is released into a harbour. The BNR plant uses the

133 modified Johannesburg process, which is designed with activated sludge and sequential

134 anaerobic, anoxic and aerobic reactor zones to remove ammonia, phosphorus, and

135 nitrogen. Treatment steps include primary clarifiers, BNR process reactors, two 
secondary clarifiers, and UV disinfection. The hydraulic retention time in the BNR

137 process reactors is approximately 21 hours (personal communication, plant operator).

138 The design MLSS and sludge age in the BNR process reactors are $3500 \mathrm{mg} / \mathrm{L}$ and 15

139 days, respectively. The surface overflow rates of the primary and secondary clarifiers are

14030 and $15 \mathrm{~m} / \mathrm{d}$, respectively. The UV system is a Wedeco Model TAK55L (Xylem, Rye

141 Brook, NY, USA) operated at a UV dose of $250 \mathrm{~mJ} / \mathrm{cm}^{2}$. The plant is designed to

142 produce effluent with maximum concentrations of $10 \mathrm{mg} / \mathrm{L}$ for $\mathrm{CBOD}_{5}, 10 \mathrm{mg} / \mathrm{L}$ for

143 TSS, 10 mg/L Total Nitrogen (TN) and 1 mg/L Total Phosphorus (TP). Duplicate

144 samples were collected in pre-sterilized $1 \mathrm{~L}$ Nalgene collection bottles (Thermo Fisher

145 Scientific) and collected from the raw influent (A), after the primary clarifiers (B), after

146 BNR treatment (C), after the secondary clarifiers where out-going water from the two

147 clarifiers was mixed (D), and after UV disinfection (E) as shown in Figure 1B. Samples

148 were kept on ice and transported back to the laboratory at Dalhousie University in

149 Halifax, NS (a distance of approximately $300 \mathrm{~km}$ ) for processing the following morning.

150

1512.2 Analysis of the Abundance of Antibiotic Resistance Genes, Human Fecal

152 Markers and 16S rRNA Gene Copies

153 2.2.1 Genomic DNA extraction

154 Microorganisms in wastewater samples (30 to $500 \mathrm{~mL}$ ) were concentrated either

155 by filtration through $0.45 \mu \mathrm{m}$ pore size membranes using a vacuum manifold (Millipore,

156 Inc., Bedford, MA) or centrifugation at $3200 \times g$ for 10 minutes. Filters or pellets were

157 stored at $-20^{\circ} \mathrm{C}$ until DNA extraction. Genomic DNA (gDNA) was extracted from the

158 entire filter or cell pellet using the MoBio Powersoil DNA extraction kit (VWR 

specifications. The concentration and purity of the DNA were evaluated by ultraviolet absorbance spectrophotometry at 260/280 nm and 260/230 nm (Implen Nanophotometer, Implen, München, Germany).

\subsubsection{Quantitative real-time PCR} Primer and TaqMan hydrolysis probe sequences and cycling conditions for nine

165 ARGs and one integrase gene were obtained from literature and are listed in Table S1 in 166 the Supplemental Material. The genetic targets included class 1 integrase (intl1), class A $167 \beta$-lactamase (bla $a_{\mathrm{CTX}-\mathrm{M}}$ and $\left.b l a_{\mathrm{TEM}}\right)$, erythromycin resistance gene (ermB),

168 fluoroquinolone resistance gene ( $q n r S)$, sulphonamide resistance genes (sul1 and sul2), tetracycline resistance gene (tet( $\mathrm{O}))$, methicillin resistance gene (mecA), and vancomycin resistance gene (vanA). These ARGs were chosen to represent a variety of different antibiotic classes and resistance mechanisms as well as clinically relevant genes (Szczepanowski et al., 2009; Volkmann et al., 2004). The content of bacterial 16S rRNA genes (16S rRNA) was determined by qPCR

174 (reaction conditions described in Table S1) to enumerate the total bacterial community 175 and to allow for the calculation of the relative abundance of ARG relative to the 16S 176 rRNA copy numbers. The human-specific fecal HF183 Bacteroides 16S rRNA genetic 177 marker (HF183) (Sauer et al., 2011) was also quantified to examine a potential 178 correlation between this DNA marker and ARG abundance. All targets were quantified 179 in all water samples, except for one sampling run (AL plant, July 28, 2015) where tet(O), 180 mecA, vanA and HF183 were not tested due to limitations in sample DNA quantities. 
182 (University of Western Ontario, London, ON, Canada) and described in Rahube et al.

183 (2014a). Control plasmids for bla $a_{\mathrm{CTX}-\mathrm{M}}$, ermB, $q n r \mathrm{~S}$, tet(O), mecA, and vanA were

184

185

186

187

188

described in Neudorf et al. (2017). Concentrations of plasmid DNA were quantified using the Quant-iT PicoGreen dsDNA Assay Kit (Thermo Fisher Scientific). Standard curves were constructed for each assay using tenfold serial dilutions of plasmid controls and triplicate samples. Quality assurance for standard curves were performed using recommendations from Biorad Real-Time PCR Applications Guide (BioRad, 2013). Efficiencies ranged from $87 \%$ to $111 \%$ and $R^{2}$ values were $>0.99$ for all standard curves (Table S1). Limits of quantification (LOQ) (copies/reaction) were as follows: intl1=14.4, sul1=11.7, sul2=9.6, tet(O)=69.0, ermB $=13.8$, bla $_{\mathrm{CTX}-\mathrm{M}}=6.2, b l a_{\mathrm{TEM}}=243.0$, qnrS $=112.0$, mecA $=69.0$, vanA $=138.0,16 \mathrm{~S}$ rRNA=67000, HF183=3630. Limit of detection (LOD) was 5 copies/reaction (or 1 copy/mL for $500 \mathrm{~mL}$ sample volumes and 10 copies/mL for $50 \mathrm{~mL}$ sample volumes).

TaqMan qPCR assays for the ARG markers were performed on a Bio-Rad CFX96 Touch system (Bio-Rad, Hercules, CA, USA). The following reaction mixture was used: 1 x SsoAdvanced ${ }^{\mathrm{TM}}$ Universal Probes Supermix (Bio-Rad), $0.9 \mu \mathrm{M}$ of each primer, 0.25 $\mu \mathrm{M}$ TaqMan probe, $2 \mu \mathrm{L}$ template DNA, and $2 \mu \mathrm{L}$ of sterile nuclease-free water (Thermo Fisher) to a final volume of $20 \mu \mathrm{L}$. A Taqman qPCR assay was also used in quantification of the human faecal HF183 Bacteroides marker, where the following reaction mixture was used: 1 x SsoAdvanced ${ }^{\mathrm{TM}}$ Universal Probes Supermix (Bio-Rad), $0.6 \mu \mathrm{M}$ of each primer, $0.25 \mu \mathrm{M}$ TaqMan probe, $2 \mu \mathrm{L}$ template DNA, and $6.5 \mu \mathrm{L}$ of sterile nuclease-free water (Thermo Fisher Scientific) to a final volume of $25 \mu \mathrm{L}$. SYBR 
204 Green qPCR was used to quantify bacterial 16S rRNA gene copy numbers and for this 205 assay, the following reaction mixture was used: 1x Power SYBR ${ }^{\circledR}$ Green PCR Master 206 Mix (Applied Biosystems, Foster City, CA, United States), $0.4 \mu \mathrm{M}$ primers, and $1 \mu \mathrm{L}$ of 207 template DNA, and 7.4 $\mu \mathrm{L}$ of sterile nuclease-free water (Thermo Fisher Scientific) to a 208 final volume of $20 \mu \mathrm{L}$. Samples and negative controls (no template DNA) were analyzed 209 in duplicate, while standards (control plasmid) reactions were analyzed in triplicates. 210 Raw fluorescence data from the Bio-Rad CFX96 Touch system were imported 211 into the LinRegPCR program (v. 11.4) (Ruijter et al., 2009). For each primer set and 212 qPCR run, the fluorescence threshold was set to obtain a cycle threshold (CT) value for 213 the positive control that matched the concentration specific CT value from the previously 214 established standard curve. The LinRegPCR program automatically calculated the 215 individual sample's CT and $\mathrm{E}_{\mathrm{fi}}$ (efficiency estimated from fluorescence increase) values. 216 In order to account for differences in efficiencies between samples and standards, a one217 point calibration method for absolute quantification was used (Brankatschk et al., 2012).

218 For statistical analyses, any values that fell between the LOD and LOQ were set to $1 / 2$ 219 LOQ value while values that fell below the LOD were set to $1 / 2$ LOD. For calculation of 220 the relative abundance of genes, the gene copy number of each gene was normalized to 221 the gene copy number of the 16S rRNA gene in each sample and log transformed 222 (log(ARG gene copies/16S rRNA gene copies)). For calculation of the absolute 223 abundance of genes, gene copies were normalized to the water volume used for gDNA 224 extractions to generate gene copies per $\mathrm{mL}$ of water. For the AL plant, the calculation of 225 absolute abundance was done for samples from August and February. 


\subsection{Assessment of Water Quality}

Water samples were analysed within the recommended holding times of 24-48

229 hours for the following water quality parameters: CBOD $_{5}$, TSS, volatile suspended solids

230 (VSS), TN, ammonia, nitrate, TP, chemical oxygen demand (COD), total coliforms, and

231 E. coli.

Analysis of $\mathrm{CBOD}_{5}$ was performed in duplicate according to the APHA standard

233 method 5210B (American Public Health Association, 2005). TSS and VSS were

234 performed using Whatman ${ }^{\mathrm{TM}}$ 934-AH 47 mm glass fiber filters (Thermo Fisher

235 Scientific) according to APHA standard methods 2540 D (American Public Health

236 Association, 2005). TN was analyzed using Hach ${ }^{\circledR}$ TN Test ' $\mathrm{N}$ Tubes ${ }^{\mathrm{TM}}$ (0.5 to 25.0

$237 \mathrm{mg} / \mathrm{L} \mathrm{N}$, Hach Company, Loveland, CO, United States), according to the manufacturer's

238 procedure. Ammonia and nitrate were measured using high performance ammonia and

239 nitrate electrodes, respectively, as directed by the manufacturer (Thermo Fisher

240 Scientific). The electrodes were attached to an Orion Star ${ }^{\mathrm{TM}}$ series meter (Thermo Fisher

241 Scientific). TP was analyzed using $\operatorname{Hach}^{\circledR}$ TP Test 'N Tube ${ }^{\mathrm{TM}}$ ranging from 1.0 to 100.0

$242 \mathrm{mg} / \mathrm{L} \mathrm{PO} 4^{3-}$ (Hach Company), following the manufacturer's procedure. COD was

243 analyzed using Hach ${ }^{\circledR}$ COD TNT plus Vial ${ }^{\text {TM }}$ Test ranging from 20 - 1500 mg/L COD

244 (Hach Company), following the manufacturer's procedure. Total coliforms and E. coli

245 were enumerated using IDEXX Colilert ${ }^{\circledR}-18$ and Quanti-Trays ${ }^{\circledR}$ (IDEXX Laboratories,

246 Inc., Westbrook, ME, United States) according to the manufacturer's instructions

247 (IDEXX Laboratories, Inc., 2012). 


\subsection{Detection of Antibiotics in Water Samples}

Water samples from the August and February sampling events at the AL plant and from both sampling events at the BNR plant were tested for the content of 10 antibiotics (amoxicillin, cefaclor, cefprozil, cefdinir, levofloxacin, ciprofloxacin, azithromycin, clindamycin, clarithomycin, and triclocarban) at Acadia University (Wolfville, NS, Canada).

\subsubsection{Sample Preparation for Antibiotic Detection} The $\mathrm{pH}$ of the samples $(100 \mathrm{~mL})$ was adjusted to $\mathrm{pH} 2.5 \pm 0.5$ with $1 \mathrm{M} \mathrm{HCl}$. The samples were then pumped ( $5 \mathrm{~mL} / \mathrm{min})$ through a vacuum filter apparatus equipped with 3 mL Chromabond $®$ HR-X (200 mg sorbent) solid phase extraction columns, which had been pre-conditioned with $6 \mathrm{~mL}$ methanol and $6 \mathrm{~mL}$ of deionized (DI) water. Sample cartridges were then washed with $3 \mathrm{~mL}$ of $10 \%(\mathrm{v} / \mathrm{v})$ methanol in DI and dried for $5 \mathrm{~min}$ under vacuum followed by the elution of analytes with $6 \mathrm{~mL}$ of methanol. Eluents were collected and reduced to $1 \mathrm{~mL}$ with gentle nitrogen blowdown at $37^{\circ} \mathrm{C}$.

\subsubsection{Quantification of Antibiotics}

Antibiotic analysis was performed using an Agilent 1200 HPLC (Santa Clara, CA, USA) coupled with an Agilent 6410B triple quadrupole mass spectrometer. Chromatographic separation was performed using a 15-cm Agilent Poroshell Eclipse C18 column with a $4.6-\mathrm{mm}$ internal diameter and $2.7-\mu \mathrm{m}$ particles. The mobile phase consisted of $0.1 \%(\mathrm{v} / \mathrm{v})$ formic acid buffer. The flow rate of mobile phase was 0.5 $\mathrm{mL} / \mathrm{min}$. A solvent gradient was programmed to start at 20\% (v/v) methanol for 30 
seconds, which increased to $100 \%(\mathrm{v} / \mathrm{v})$ by 20 minutes. The column was held at a constant temperature of $40^{\circ} \mathrm{C}$. Following separation, ionization was conducted with an electrospray ionization source under 35-psi nebulizer pressure. Drying gas temperature was set to $350^{\circ} \mathrm{C}$ with a flow rate of $12 \mathrm{~L} / \mathrm{min}$. The mass spectrometer was operated in the positive ion mode and the capillary voltage was held at $4000 \mathrm{~V}$. Nebulizing gas and collision gas consisted of 98\% nitrogen and ultra-high purity (UHP, 99.999 \%) nitrogen, respectively. Precursor-to-product ion transitions were established for all target antibiotics. To boost the sensitivity of analysis, only one transition was monitored for each compound. Fragmentor voltage and collision energy were carefully optimized to achieve maximum response for each transition. The mass spectrometer parameters and transitions are shown in the supplementary information Table S2.

\subsubsection{Quality assurance and quality control}

To assist with quality assurance and quality control, solvent blank samples were included. Sampling bottles were pre-cleaned by manufacturers. These bottles and other glassware were thoroughly cleaned using DI water and methanol. Salinization of glassware was not performed because spiked samples did not show loss of target compounds. containing $5 \mathrm{~g}$ of sodium chloride with an antibiotic mixture and subjecting the sample to

292 the same analytical method. The recoveries of the target antibiotics were analyzed and reported. An internal standard was used to ensure the quality of instrumental analysis and 
sample preparation. Duplicates were included to verify the reproducibility of the analytical method.

296

\subsection{Data Analysis}

One-way analysis of variance (ANOVA), Tukey HSD test, and t-tests were used to assess statistically significant differences $(\mathrm{p}<0.05)$ among samples. Log reductions were calculated as the log difference between treatment steps or influent/effluent. Pearson correlation coefficients were calculated (after performing check of normality) to assess if significant $(\mathrm{p}<0.05)$ correlations existed between the total ARG marker concentrations and water quality parameters. Analysis was performed using GraphPad Prism version 7.00 for Mac OS X (GraphPad Software, La Jolla California USA, www.graphpad.com), and Microsoft Excel, 2016. The total ARG marker concentrations were calculated as the average of the sum of all tested ARG marker concentrations in the samples for each individual sample site and run.

308

\section{Results and Discussion}

3.1 The absolute abundance of ARGs during treatment in the AL and BNR plants Measurements of water quality parameters and content of ARGs revealed no

313 significant differences ( $\mathrm{p}>0.05$ ) between sample runs, indicating consistent performance

314 of the WWTPs. For further analysis, the averages of the results from all sample runs are 315 presented. 
317 and vanA (never detected above LOD), were consistently detected in the municipal

318 wastewater arriving at both WWTPs (Figures 2 and 3). Other WWTP studies have

319 reported detection of mecA and vanA, which confer resistance to methicillin and

320 vancomycin, respectively, both of which are antibiotics of last resort (Narciso-da-rocha et

321 al., 2014; Szczepanowski et al., 2009; Volkmann et al., 2004). The low levels or absence

322 of these targets in this study may be due to the fact that these WWTPs were servicing

323 smaller urban centres ( $<15,000$ people). Furthermore, mecA and vanA genes can be

324 present on chromosomal DNA as opposed to plasmids (Biavasco et al., 2007; Cetinkaya

325 et al., 2000; Colomer-Lluch et al., 2011; Katayama et al., 2000) resulting in a limited

326 range of host bacteria with lower presence/survival in the WWTP environment

327 (Goldstein et al., 2012). ARGs belonging to the tet and sul families were detected in all

328 influent samples and represent resistance genes to some of the oldest and most commonly 329 consumed antibiotics (Al-Jassim et al., 2015; Auerbach et al., 2007; Du et al., 2015; Laht 330 et al., 2014; LaPara et al., 2011). Other less studied ARGs (qnrS, ermB, bla $a_{\mathrm{CTX}-\mathrm{M},}$ bla $\left.a_{\mathrm{TEM}}\right)$

331 have also been previously detected in wastewater samples, and represent genes that are

332 often plasmid-borne and confer resistance to the latest generations of antibiotics (Marti et

333 al., 2013; Narciso-da-Rocha et al., 2014; Rodriguez-Mozaz et al., 2014).

334 Overall, the AL treatment continuum led to a significant $(\mathrm{p}<0.05)$ decrease in the 335 total ARG marker abundance of 1.77 log copies/mL from the influent sewage (total ARG 336 of $6.29 \log$ copies/mL) to the treated effluent (total ARG of $4.52 \log$ copies/mL (Figure 337 2A). Total ARG concentrations decreased by the following log copies/mL after each 338 treatment step: 0.16 (AL), 1.54 (secondary clarifier), 0.26 (sand filters), -0.20 (UV). This 
showed that the secondary clarifiers were responsible for the largest incremental removal

340 of ARGs, an observation agreeing with the result from the BNR plant (see below) and

341 WWTP2 in the study of Lee et al. (2017). This removal may likely have occurred through

342 the sedimentation processes and may imply that the generated biosolids contain a large

343 amount of the ARGs, as has previously been observed (Börjesson et al., 2010; Chen and

344 Zhang, 2013; Mao et al., 2015; Nnadozie et al., 2018). The AL, sand filters and UV

345 treatment steps contributed little to the removal of ARGs in this WWTP.

346 In the AL plant, the content of individual genes exhibited, with the exception of

347 sul1 and bla $a_{\mathrm{CTX}-\mathrm{M}}$, significant $(\mathrm{p}<0.05)$ decreases from $0.94 \log$ copies $/ \mathrm{mL}(\mathrm{mecA})$ to

$3482.23 \log$ copies/mL ( $q n r S$ ), when comparing the influent and effluent water samples

349 (Figure 2A). Previous research has suggested that sulfamethoxazole-resistant bacteria are

350 difficult to remove (Gao et al., 2012), which may explain the insignificant reduction of

351 sul1. The significant $(\mathrm{p}<0.05) 1.74 \log$ copies/mL decrease in the AL plant's absolute

352 abundance of 16S rRNA gene from $9.23 \log$ copies/mL in the influent to $7.49 \log$

353 copies/mL in the effluent (Figure 2C) was similar to the decrease in the total ARG

354 concentration. Individual ARG concentration levels ranged from 3.27 (mec A) to 5.85

355 (qnrS) and from 2.32 (mecA) to 4.15 (int11) log copies/mL in the influent and effluent

356 samples, respectively.

357 In the BNR plant, there was a significant $(\mathrm{p}<0.05)$ decrease in total ARG

358 concentration of $2.69 \log$ copies/mL, from 7.01 in the raw influent to 4.33 log copies $/ \mathrm{mL}$

359 in the effluent (Figure 3A). After the individual treatment steps, the total ARG

360 concentration decreased by the following log copies/mL: 0.15 (primary clarifier), 1.36

361 (BNR), 0.62 (secondary clarifiers), 0.56 (UV). This means that in comparison to the AL 
plant, the total ARG removal in the BNR plant was 0.92 log copies $/ \mathrm{mL}$ or $88 \%$ higher (2.69 vs. $1.77 \log$ copies/mL). Moreover, the BNR treatment step was responsible for the largest incremental removal of ARGs in the wastewater system; this was in contrast to the minimal removal observed in the biological treatment unit (i.e., the mechanically aerated lagoons) of the AL plant. The finding that the BNR plant's sequential use of anaerobic, anoxic and aerobic reactors improved the removal of ARGs concurs with reports by Munir et al. (2011), Du et al. (2015) and Lee et al. (2017), who studied WWTPs with similar combinations of reactors with different oxygen conditions. Both the secondary clarification and the UV treatment in the BNR plant contributed significantly $(\mathrm{p}<0.05)$ to the removal of ARGs. The UV doses were 50 and $250 \mathrm{~mJ} / \mathrm{cm}^{2}$ in the AL and BNR plants, respectively, which likely explained the larger ARG log removal of 0.56 after this step in the BNR plant as compared to no decrease at the AL plant. In agreement with our observations, Lee et al. (2017) reported no decrease in ARGs following UV disinfection at a dosage of $27 \mathrm{~mJ} / \mathrm{cm}^{2}$ in two different WWTPs, while Zhang et al. (2015) reported similar log reductions for various ARGs after a UV dose of $250 \mathrm{~mJ} / \mathrm{cm}^{2}$.

Decreases in individual ARG genes from influent to effluent ranged from 2.20 (mecA) to 3.26 (bla СтX-м $_{\text {) }} \log$ copies/mL. Interestingly, Helt (2012) and Börjesson et al. (2010) observed lower log removals of between 1.26 and $1.62 \log$ copies/mL in a pilot and full scale BNR system, respectively, which were removal levels similar to those reported for the AL plant in the present study. The absolute abundance of the 16S rRNA gene decreased significantly $(\mathrm{p}<0.05)$ by $1.84 \log$ copies/mL from 9.36 to $7.52 \log$ copies/mL in the influent and effluent, respectively (Figure 2C). This indicated a lower relative reduction of the total bacterial population than of the ARGs, whose concentration 
385 levels (log copies/mL) ranged from 2.21 (mecA) to 6.65 (intl1) in the influent and from 3860.01 (mecA) to 4.09 (intl1) in the effluent.

387

\subsection{Relative abundance of ARGs at the AL and BNR plants}

390 abundance of the total ARG and the individual ARG markers between wastewater

391 treatment steps, except for sul2, whose relative abundance significantly $(\mathrm{p}<0.05)$

392 increased after the lagoon step (Figure 2B). Hence, there was neither a relative meaning that the total bacterial community (here represented by 16S rRNA gene copies) and antibiotic resistant bacteria were being reduced at comparable rates. As such it appeared that the AL plant neither selected for or against bacteria harbouring ARGs. This has, to the best of our knowledge, not previously been shown for AL type WWTPs. the relative total ARG abundances remained unchanged ( $p>0.05)$ through the different treatment steps (Figure 3B). However, when examining each gene individually, the

401 relative abundance of most genes tended to decrease after the BNR step (significant $402(\mathrm{p}<0.05)$ for bla $\left._{\mathrm{CTX}-\mathrm{M}}\right)$, with the exception of sul2 and mecA, which increased slightly 403 (Figure 3B) (also observed for sul2 at the AL plant). These results indicate that the BNR 404 biological treatment may more efficiently decrease bacteria carrying ARGs than the AL

405 treatment. It may be that the processes designed to remove nutrients may not favour 406 bacteria harbouring the surveyed ARGs leading to the lower abundances of these 407 bacterial communities after BNR treatment. The literature is still conflicting on whether 
the relative abundance is changed in WWTPs as Mao et al. (2015) observed increases in

409 the relative ARG abundance in two Chinese WWTPs while Di Cesare et al. (2016) and

410 Bengtson-Palme et al. (2016) saw the opposite trend or no change in water samples from

411 three Italian and three Swedish WWTPs, respectively. Besides varying operational

412 parameters which make direct comparisons difficult, the nature of the raw wastewater

413 may also be important. This was indicated in the study of two WWTPs using a series of

414 anoxic, anaerobic and aerobic reactors as well as sedimentation, coagulation, filtration

415 and UV, where the WWTP receiving predominantly municipal and industrial wastewater

416 reported reduction in the relative abundance of several ARGs (tet, sul, erm, qnr, bla)

417 while the relative abundance was enriched for sul, qnr and bla in the WWTP receiving a

418 higher load of agricultural wastewater (Lee et al. 2017). .

419 At both plants, intl1 became the most detected gene in the effluent (Figures 2A, B

420 and 3A, B). This was also observed by Narciso-da-Rocha et al. (2014), who suggested

421 that intl1 may be stable in wastewater. The detection of the gene marker for class I

422 integrons in wastewater may provide a global perspective on antibiotic resistance and

423 ARGs as integrons have the ability to carry and allow the transfer of multiple ARGs

424 (Rizzo et al., 2013; Rahube et al., 2014b).

425

4263.3 Changes in E. coli and HF183 human Bacteroides marker concentrations

427 Treatment at both plants significantly $(\mathrm{p}<0.05)$ decreased average $E$. coli counts

428 from 4.7-5.3 log MPN/mL in the influent to effluent values of $<0.01 \mathrm{MPN} / \mathrm{mL}$ (Figures

429 2C and 3C). The human Bacteroides fecal HF183 marker also decreased significantly

$430(\mathrm{p}<0.05)$ at both plants, with removals of 2.2 and $2.6 \log$ copies/mL from the influent to 
431 effluent water samples at the AL and BNR plants, respectively. Removal of E. coli and 432 the HF183 marker at the AL plant showed no correlation to the total ARG marker 433 concentrations ( $>$ >0.05), indicating no link between the removal of antibiotic resistance 434 related genes and E. coli or the HF183 marker. This was contrasted by the data from the 435 BNR plant, where the Pearson correlation coefficient ( $r=0.97)$ for the human HF183 436 marker in relation to total ARG marker concentrations was significant $(\mathrm{p}<0.05)$,

437 indicating that removal of the selected gene markers of antibiotic resistance and the

438 marker of human fecal contamination followed the same trend. Future research is

439 recommended to investigate the correlations between ARGs and E. coli/molecular fecal 440 markers in other WWTPs to assess the mechanisms and relevance of these indicators for 441 prediction of ARG removal.

442 Treatment in both the AL and BNR plants caused a $6 \log$ MPN/mL decrease in 443 viable E. coli counts but only around 2-3 log decreases for ARGs, 16S rRNA and HF183 444 gene copies/mL. The use of qPCR for detection of genetic elements, such as ARGs and 445 HF183, to monitor removal or inactivation of fecal indicator bacteria in wastewater may 446 be problematic as the decrease in genetic markers may not follow decreases in viable 447 bacteria levels due to possible detection of markers from dead cells or cell-free DNA 448 (Chern et al., 2014: Zhang et al., 2018). This phenomenon is likely observed in Figures 2 449 and 3, where the UV disinfection step significantly reduced culturable E. coli counts, 450 while ARG, 16S rRNA and HF183 copies/mL remained unchanged. However, 451 exogenous DNA can still be transferred to other bacteria through transformation (Frost et 452 al., 2005), especially while in presence of selective pressures (e.g., antibiotics and 
453 metals), therefore extracellular ARGs entering the environment through effluent

454 discharge may still present a possible threat to public health.

455

456

457

458

459

460

\subsection{Water quality assessment and correlation to gene abundance} parameters decreased between 0.5 and 2 orders of magnitude (Table 1), with the exception of nitrate which was increased due to conversion of ammonia into nitrate (nitrification). The plant met the regulatory targets of $5 \mathrm{mg} / \mathrm{L}$ for both TSS and $\mathrm{CBOD}_{5}$ in the effluent. In regard to correlations between total ARG concentrations and water quality at the tested sites, nitrate $(r=-0.92, \mathrm{p}<0.05)$ and $\mathrm{CBOD}_{5}(\mathrm{r}=0.95, \mathrm{p}<0.05)$ showed significant correlations (Table 1), suggesting that decreasing $\mathrm{CBOD}_{5}$ and increasing nitrate levels may help predict a decrease in ARGs in wastewater effluent from this type of plant design.

The BNR plant also met its regulatory targets of reducing TSS and $\mathrm{CBOD}_{5}$ to below $25 \mathrm{mg} / \mathrm{L}$ with its efficient removal of nutrients and solids (Table 2). While there was a trend toward $\mathrm{COD}, \mathrm{CBOD}_{5}$ and ammonia correlating with ARG removal, these relationships were not statistically significant $(\mathrm{p}>0.05)$. suggested in other studies (Börjesson et al., 2010; Du et al., 2015; Nõlvak et al., 2013;

472 Novo and Manaia, 2010). Similar to the AL plant, Nõlvak et al. (2013) found significant

473 correlations between nitrate (negative) and organic matter (positive) with ARG concentrations. Further testing would be needed for the BNR plant to determine if the trends observed would become significant. 


\subsection{Antibiotic Results and Correlations}

All tested antibiotics, besides cefprozil and cefaclor, were detected in various samples from both plants (Supplemental material Tables S3 and S4). Of the tested

480 penicillin antibiotics, only amoxicillin and cefdinir were detected despite their high

481 consumption, which may be due to their chemical instability (Graham et al., 2011). The

482 tested macrolides (azithromycin, clindamycin and clarithromycin) were detected in

483 samples obtained after all treatment steps indicating their poor removal in both WWTPs

484 as was also observed by Marx et al. (2015) and Bengtson-Palme et al. (2016).

485 Interestingly, both influent and effluent water samples from the AL plant showed higher 486 concentrations of antibiotics compared to the BNR plant, a fact which warrants further 487 investigations and may have contributed to the lower ARG removals in the AL plant. 488 Correlation analysis was performed and showed no significant $(\mathrm{p}<0.05)$ relationships 489 between the individual ARG absolute concentrations and the antibiotics they confer 490 resistance to (see Table S2). Other studies have found correlations in the past (Gao et al., 491 2012; Gao et al., 2015; Rodriguez-Mozaz et al., 2015), while Bengtson-Palme et al. 492 (2016) found none. Possible correlations may depend on the class of antibiotics since 493 their transport and/or susceptibility to degradation vary markedly (Marx et al., 2015; 494 Nnadozie et al., 2017). 


\section{Conclusions}

497 The tertiary WWTPs reduced effluent ARG marker concentrations by approximately 2

$498 \log$ copy/mL but were still releasing total ARG markers in the order of $1.3 \times 10^{14}$ and 2.8

$499 \times 10^{14}$ copies/day for the AL and BNR plant, respectively. The best removal was obtained

500 in the BNR reactors (modified Johannesburg process), which uses a series of reactors

501 with anoxic, anaerobic and aerobic reactors, as opposed to the aerobic AL lagoons. The

502 secondary clarifiers effected significant removal of ARGs in both WWTPs and did a high

503 UV dose of $250 \mathrm{~mJ} / \mathrm{cm}^{2}$ in the BNR plant. The relative abundance of ARGs generally

504 remained unchanged in samples taken along the entire treatment train of the AL and BNR

505 plant, indicating that these types of wastewater treatment systems do not promote the

506 enrichment of ARGs in the bacterial population. Changes in organic matter and the

507 removal of the human fecal HF183 marker may be useful in predicting ARG removal,

508 however, further testing is needed to solidify these relationships.

\section{Acknowledgments}

511 We would like to thank the local authorities for allowing us access to the two

512 wastewater treatment plants. We would also like to thank our team members for their

513 assistance in the field and laboratory (Audrey Hiscock, Robert Johnson, Amy Jackson,

514 and Joanna Poltarowicz). Funding for this project was provided by the Natural Science

515 and Engineering Research Council of Canada (STPGP 463352 - 14). 
Al-Jassim, N., Ansari, M.I., Harb, M., Hong, P.-Y., 2015. Removal of bacterial contaminants and antibiotic resistance genes by conventional wastewater treatment processes in Saudi Arabia: Is the treated wastewater safe to reuse for agricultural irrigation? Water Res. 73, 277-290. doi:10.1016/j.watres.2015.01.036

Allen, H.K., Donato, J., Wang, H.H., Cloud-Hansen, K. A, Davies, J., Handelsman, J., 2010. Call of the wild: antibiotic resistance genes in natural environments. Nat. Rev. Microbiol. 8, 251-259. doi:10.1038/nrmicro2312

American Public Health Association (APHA), 2005. Standard methods for the examination of water and waste water. 21st ed. Washington, DC: American Public Health Association

Auerbach, E.A., Seyfried, E.E., McMahon, K.D., 2007. Tetracycline resistance genes in activated sludge wastewater treatment plants. Water Res. 41, 1143-1151. doi:10.1016/j.watres.2006.11.045

Barancheshme, F., Munir, M. 2018. Strategies to combat antibiotic resistance in the wastewater plants. Front. Microbiol. 8, 2603. doi:10.3389/fmicb.2017.02603

Baquero, F., Martínez, J.L., Cantón, R., 2008. Antibiotics and antibiotic resistance in water environments. Curr. Opin. Biotechnol. 19, 260-265. doi:10.1016/j.copbio.2008.05.006

Batt, A.L., Kim, S., Aga, D.S., 2007. Comparison of the occurrence of antibiotics in four full-scale wastewater treatment plants with varying designs and operations. Chemosphere 68, 428-435. doi:10.1016/j.chemosphere.2007.01.008

Bengtson-Palme, J., Hammerén, R., Pal, C., Östman, M., Björnlenius, B., Flach, C-F., Fick, J., Tysklind, M., Larsson, D.G.J., 2016. Elucidating selection processes for antibiotic resistance in sewage treatment plants using metagenomics. Sci. Tot. Environ. 572, 697-712. http://dx.doi.org/10.1016/j.scitotenv.2016.06.228

Biavasco, F., Foglia, G., Paoletti, C., Zandri G., Magi, G., Guaglianone, E., Sundsfjord, A., Pruzzo, C., Donelli, G., Facinelli, B., 2007. VanA-type enterococci from humans, animals, and food: species distribution, population structure, Tn1546 typing and location, and virulence determinants. Appl. Environ. Microbiol. 73, 3307-3319.

Bio-Rad, 2013. CFX384 / CFX96 Touch TM Real-Time PCR Detection Systems 
Instruction Manual, Manual.

Börjesson, S., Mattsson, A., Lindgren, P.E., 2010. Genes encoding tetracycline resistance in a full-scale municipal wastewater treatment plant investigated during one year. J. Water Health, 8, 247-256. doi:10.2166/wh.2009.159

Brankatschk, R., Bodenhausen, N., Zeyer, J., Burgmann, H., 2012. Simple absolute quantification method correcting for quantitative PCR efficiency variations for microbial community samples. Appl. Environ. Microbiol. 78, 4481-4489. doi:10.1128/AEM.07878-11

Cetinkaya, Y., Falk, P., Mayhall, C.G., 2000. Vancomycin-resistant Enterococci. Clin. Microbiol. Rev. 13(4), 686-707.

Chen, H., Zhang, M., 2013. Effects of advanced treatment systems on the removal of antibiotic resistance genes in wastewater treatment plants from Hangzhou, China. Environ. Sci. Technol. 47, 8157-8163.

Chern, E.C., Brenner, K., Wymer, L., Haugland, R.A., 2014. Influence of wastewater disinfection on densities of culturable fecal indicator bacteria and genetic markers. J Water Health. 12(3), 410-417.

Colomer-Lluch, M., Jofre, J., Muniesa, M., 2011. Antibiotic resistance genes in the bacteriophage DNA fraction of environmental samples. PLoS ONE. 6(3), 1-11.

Czekalski, N., Berthold, T., Caucci, S., Egli, A., Bürgmann, H., 2012. Increased levels of multiresistant bacteria and resistance genes after wastewater treatment and their dissemination into Lake Geneva, Switzerland. Front. Microbiol. 3:106. http://dx.doi. org/10.3389/fmicb.2012.00106.

Davies, J., Davies, D., 2010. Origins and evolution of antibiotic resistance. Microbiol. Mol. Biol. Rev. 74, 417-433. doi:10.1128/MMBR.00016-10

Di Cesare, A., Eckert, E.M., D'Urso, S., Bertoni, R., Gillan, D., Wattiez, R., Corno, G., 2016. Co-occurrence of integrase 1 , antibiotic and heavy metal resistance genes in municipal wastewater treatment plant. Water Res. 94, 208-214. http://dx.doi.org/10.1016/j.watres.2016.02.049

Du, J., Geng, J., Ren, H., Ding, L., Xu, K., Zhang, Y., 2015. Variation of antibiotic resistance genes in municipal wastewater treatment plant with A2O-MBR system. Environ. Sci. Pollut. Res. 22, 3715-3726. doi:10.1007/s11356-014-3552-X 
600

601

602

603

604

605

606

607

608

609

610

611

612

613

614

615

616

617

618

619

620

621

622

623

624

625

626

627

628

629

630

631

632

633

634

635

636

637

638

639

640

641

642

Environment Canada, 2015. Wastewater Systems Effluent Regulations. http://www.ec.gc.ca/eu-ww/. Accessed 14 June 2018.

Frost, L.S., Leplae, R., Summers, A.O., Toussaint, A., 2005. Mobile genetic elements: the agents of open source evolution. Nat. Rev. Microbiol. 3, 722-732. doi:10.1038/nrmicro1235

Gao, P., He, S., Huang, S., Li, K., Liu, Z., Xue, G., Sun, W., 2015. Impacts of coexisting antibiotics, antibacterial residues, and heavy metals on the occurrence of erythromycin resistance genes in urban wastewater. Appl. Microbiol. Biotechnol. 99, 3971-3980. doi:10.1007/s00253-015-6404-9

Gao, P., Munir, M., Xagoraraki, I., 2012. Correlation of tetracycline and sulfonamide antibiotics with corresponding resistance genes and resistant bacteria in a conventional municipal wastewater treatment plant. Sci. Total Environ. 421-422, 173-183. doi:10.1016/j.scitotenv.2012.01.061

Graham DW, Olivares-Rieumont S, Knapp CW, Lima L, Werner D, et al., 2011. Antibiotic resistance gene abundances associated with waste discharges to the Almendares River near Havana, Cuba. Environ Sci Technol. 45, 418-424.

Goldstein, R.E.R., Micallef, S., Gibbs, S., Davis, J., George, A., Kleinfelter, L., et al., 2012. Methicillin-resistant Staphylococcus aureus detected at four U.S. wastewater treatment plants. Environ. Health Perspect. 120, 1551-1558.

Helt, C., 2012. Occurrence, fate, and mobility of antibiotic resistant bacteria and antibiotic resistance genes among microbial communities exposed to alternative wastewater treatment systems. (Doctoral thesis). University of Waterloo, Ontario, Canada.

Katayama, Y., Ito, T., Hiramatsu, K., 2000. A new class of genetic element, Staphylococcus cassette chromosome mec, encodes methicillin resistance in Staphylococcus aureus. Antimicrob. Agents Chemother. 44(6), 1549-1555.

Laht, M., Karkman, A., Voolaid, V., Ritz, C., Tenson, T., Virta, M., Kisand, V., 2014. Abundances of tetracycline, sulphonamide and beta-lactam antibiotic resistance genes in conventional wastewater treatment plants (WWTPs) with different waste load. PLoS One, 9, 1-8. doi:10.1371/journal.pone.0103705

LaPara, T.M., Burch, T.R., Mcnamara, P.J., Tan, D.T., Yan, M., Eichmiller, J.J., 2011. Tertiary-treated municipal wastewater is a significant point source of antibiotic resistance genes into Duluth-Superior Harbor. Environ. Sci. Technol. 45, 95439549. 
643

644

645

646

647

648

649

650

651

652

653

654

655

656

657

658

659

660

661

662

663

664

665

666

667

668

669

670

671

672

673

674

675

676

677

678

679

680

681

682

683

684

Lee, J., Jeon, J.H., Shin, J., Jang, H.M., Kim, S., Son, M.S., Kim, Y.M. 2017.

Quantitative and qualitative changes in antibiotic resistance genes after passing through treatment processes in municipal wastewater treatment plants. Sci. Total Environ. 605-606, 906-914.

Levy, S.B., Marshall, B., 2004. Antibacterial resistance worldwide: causes, challenges and responses. Nat. Med. 10, S122-S129. doi:10.1038/nm1145

Mao, D.,, Yu, S., Rysz, M., Luo, Y., Yang, F., Li, F., Hou, J., Mu, Q, Alvarez, P.J.J. 2015. Prevalence and proliferation of antibiotic resistance genes in two municipal wastewater treatment plants. Water Res. 85, 458-466.

Marti, E., Jofre, J., Balcazar, J.L., 2013. Prevalence of antibiotic resistance genes and bacterial community composition in a river influenced by a wastewater treatment plant. PLoS One, 8, 1-8.

Martinez, J.L., 2009. Environmental pollution by antibiotics and by antibiotic resistance determinants. Environ. Pollut. 157, 2893-2902. doi:10.1016/j.envpol.2009.05.051

Marx, C., Günther, N., Schubert, S., Oertel, R., Ahnert, M., Krebs, P., Kuehn, V. 2015. Mass flow of antibiotics in a wastewater treatment plant focusing on removal variation due to operational parameters. Sci. Total Environ. 538, 779-788. http://dx.doi.org/10.1016/j.scitotenv.2015.08.112

Munir, M., Wong, K., Xagoraraki, I., 2011. Release of antibiotic resistant bacteria and genes in the effluent and biosolids of five wastewater utilities in Michigan.Water Res. 45, 681-693. doi: 10.1016/j.watres.2010.08.033

Narciso-da-Rocha, C., Varela, A.R., Schwartz, T., Nunes, O.C., Manaia, C.M., 2014. Resistance $b a_{T E M}$ and $v a n A$ as indicator genes of antibiotic resistance contamination in a hospital - urban wastewater treatment plant system. J. Glob. Antimicrob. Resist. 2, 309-315. doi:10.1016/j.jgar.2014.10.001.

Neudorf, K., Huang, Y.N., Ragush, C., Yost, C., Jamieson, R., Truelstrup Hansen, L., 2017. Antibiotic resistance genes in municipal wastewater treatment systems and receiving waters in Arctic Canada. Sci. Total Environ. 598, 1085-1094. doi:10.1016/j.scitotenv.2017.04.151

Nnadozie, C.F., Kumari, S., Bux, F. 2017. Status of pathogens, antibiotic resistance genes and antibiotic residues in wastewater treatment systems. Rev. Environ. Sci. Biotechnol. 16, 491-515. doi: 10.1007/s11157-017-9438-x 
685

686

687

688

689

690

691

692

693

694

695

696

697

698

699

700

701

702

703

704

705

706

707

708

709

710

711

712

713

714

715

716

717

718

719

720

721

722

723

724

725

726

727

Nõlvak, H., Truu, M., Tiirik, K., Oopkaup, K., Sildvee, T., Kaasik, A., Mander, Ü., Truu, J., 2013. Dynamics of antibiotic resistance genes and their relationships with system treatment efficiency in a horizontal subsurface flow constructed wetland. Sci. Total Environ. 461-462, 636-644. doi:10.1016/j.scitotenv.2013.05.052

Novo, A., Manaia, C.M., 2010. Factors influencing antibiotic resistance burden in municipal wastewater treatment plants. Appl. Microbiol. Biotechnol. 87, 11571166. doi:10.1007/s00253-010-2583-6

Pruden, A., Pei, R., Storteboom, H., Carlson, K.H., 2006. Antibiotic resistance genes as emerging contaminants: Studies in northern Colorado. Environ. Sci. Technol. 40, 7445-7450. doi:10.1021/es0604131

Rahube, T.O., Marti, R., Scott, A., Tien, Y., Murray, R., Sabourin, L., Zhang, Y., Duenk, P., Lapen, D.R., Topp, E., 2014a. Impact of fertilizing with raw or anaerobically digested sewage sludge on the abundance of antibiotic-resistant coliforms, antibiotic resistant genes, and pathogenic bacteria in soil and on vegetables at harvest. Appl. Environ.Microbiol. 80, 6898-6907.

Rahube, T.O., Viana, L.S., Koraimann, G., Yost, C.K., 2014b. Characterization and comparative analysis of antibiotic resistance plasmids isolated from a wastewater treatment plant. Front Microbiol 5, 558. doi:10.3389/fmicb.2014.00558

Rizzo, L., Manaia, C., Merlin, C., Schwartz, T., Dagot, C., Ploy, M.C., Michael, I., FattaKassinos, D., 2013. Urban wastewater treatment plants as hotspots for antibiotic resistant bacteria and genes spread into the environment: a review. Sci. Total Environ. 447, 345-60. doi:10.1016/j.scitotenv.2013.01.032

Rodriguez-Mozaz, S., Chamorro, S., Marti, E., Huerta, B., Gros, M., Sànchez-Melsió, A., Borrego, C.M., Barceló, D., Balcázar, J.L., 2015. Occurrence of antibiotics and antibiotic resistance genes in hospital and urban wastewaters and their impact on the receiving river. Water Res. 69, 234-242. doi:10.1016/j.watres.2014.11.021

Ruijter, J.M., Ramakers, C., Hoogaars, W.M.H., Karlen, Y., Bakker, O., Van Den Hoff, M.J.B., Moorman, A.F.M., 2009. Amplification efficiency: Linking baseline and bias in the analysis of quantitative PCR data. Nucleic Acids Res. 37. doi:10.1093/nar/gkp045

Sanderson, H., Fricker, C., Brown, R.S., Majury, A., Liss, S.N., 2016. Antibiotic resistance genes as an emerging environmental contaminant. Environ. Rev. 218, 2739. doi:10.1139/er-2015-0069 
Sauer, E.P., VandeWalle, J.L., Bootsma, M.J., McLellan, S.L., 2011. Detection of the

Szczepanowski, R., Linke, B., Krahn, I., Gartemann, K.H., Gützkow, T., Eichler, W., Pühler, A., Schlüter, A., 2009. Detection of 140 clinically relevant antibioticresistance genes in the plasmid metagenome of wastewater treatment plant bacteria showing reduced susceptibility to selected antibiotics. Microbiology. 155, 23062319. doi:10.1099/mic.0.028233-0

Tamminen, M., Karkman, A., Lohmus, A., Muziasari, W.I., Takasu, H., Wada, S., Suzuki, S., Virta, M., 2011. Tetracycline resistance genes persist at aquaculture farms in the absence of selection pressure tetracycline resistance genes persist at aquaculture farms in the absence of selection pressure. Environ. Sci. Technol. 45, 386-391. doi:10.1021/es102725n

Volkmann, H., Schwartz, T., Bischoff, P., Kirchen, S., Obst, U., 2004. Detection of clinically relevant antibiotic-resistance genes in municipal wastewater using realtime PCR (TaqMan). J. Microbiol. Methods 56, 277-286. doi:10.1016/j.mimet.2003.10.014

Zhang, Y., Zhuang, Y., Geng, J., Ren, H., Zhang, Y., Ding, L., Xu, K., 2015. Inactivation of antibiotic resistance genes in municipal wastewater effluent by chlorination and sequential UV/chlorination disinfection. Sci. Total Environ. 512-513, 125-132.

Zhang, Y., Li, A., Dai, T., Li, F., Xie, H., Chen, L., Wen, D., 2018. Cell-free DNA: A neglected source for antibiotic resistance genes spreading from WWTPs. Env. Sci. Technol. 52, 248-257. doi:10.1021/acs.est.7b04283 


\section{Figure Legends.}

760

761 Figure 1. Schematic layout of the treatment trains of A) the aerated lagoon (AL) plant

762 and B) the biological nutrient removal (BNR) plant with sampling sites indicated by

763 letters (A-E).

764

765 Figure 2. Effect of individual treatment steps in an mechanically aerated lagoon

766 wastewater treatment plant on the absolute and relative abundances of ARGs and fecal

767 indicators in water samples (averages \pm standard deviations). a) Absolute abundances of

768 each ARG, int11 and the sum of all ARG markers (Total ARG) (n=4). b) Relative

769 abundances of each ARG, intl1 and Total ARG (n=8). c) Concentration of 16S rRNA

770 genes, E. coli and the human HF183 Bacteroides marker (n=4). (Sand is an abbreviation

771 for the sand filter)

772 
773 Figure 3. Effect of individual treatment steps in a biological nutrient removal reactor

774 wastewater treatment plant on the absolute and relative abundances of ARGs and fecal

775 indicators in water samples ( $\mathrm{n}=4$, averages \pm standard deviation). a) Absolute abundances

776 of each ARG, intl1 and the sum of all ARG markers (Total ARG). b) Relative

777 abundances of each ARG, intl1 and Total ARG. c) Concentration of 16S rRNA gene

778 copies, E. coli and the human HF183 Bacteroides marker. ( $1^{\text {st }}$ and $2^{\text {nd }}$ refer to the

779 primary and secondary clarifiers).

780 


\section{Tables.}

Table 1. AL plant water quality data and Pearson correlation coefficients (average results \pm standard deviations from four sampling events).

\begin{tabular}{|c|c|c|c|c|c|c|c|c|}
\hline & $\begin{array}{l}\text { Nitrate } \\
(\mathrm{mg} / \mathrm{L})\end{array}$ & $\begin{array}{l}\text { Ammonia } \\
\text { (mg/L) }\end{array}$ & $\mathrm{TN}(\mathrm{mg} / \mathrm{L})$ & $\begin{array}{l}\text { TSS } \\
(\mathrm{mg} / \mathrm{L})\end{array}$ & $\begin{array}{l}\text { VSS } \\
\text { (mg/L) }\end{array}$ & $\begin{array}{l}\mathrm{COD} \\
(\mathrm{mg} / \mathrm{L})\end{array}$ & TP (mg/L) & $\mathrm{CBOD}_{5}(\mathrm{mg} / \mathrm{L})$ \\
\hline Influent & $\begin{array}{l}1.5 \\
\pm 1.7 \\
\end{array}$ & $\begin{array}{l}18.8 \\
\pm 5.8 \\
\end{array}$ & $\begin{array}{l}31.3 \\
\pm 6.76 \\
\end{array}$ & $\begin{array}{l}160.9 \\
\pm 65.3 \\
\end{array}$ & $\begin{array}{l}151.2 \\
\pm 59.6\end{array}$ & $\begin{array}{l}406.1 \\
\pm 70.3\end{array}$ & $\begin{array}{l}9.4 \\
\pm 2.1\end{array}$ & $\begin{array}{l}169.3 \\
\pm 42.2\end{array}$ \\
\hline Lagoon & $\begin{array}{l}5.5 \\
\pm 2.7\end{array}$ & $\begin{array}{l}1.0 \\
\pm 0.55\end{array}$ & $\begin{array}{l}201.1 \\
\pm 41.83\end{array}$ & $\begin{array}{l}2861.3 \\
\pm 1006.0\end{array}$ & $\begin{array}{l}2332.0 \\
\pm 812.5\end{array}$ & $\begin{array}{l}4272.3 \\
\pm 1478.0\end{array}$ & $\begin{array}{l}255.6 \\
\pm 69.0\end{array}$ & $\begin{array}{l}242.3 \\
\pm 92.3\end{array}$ \\
\hline Clarifier & $\begin{array}{l}8.1 \\
\pm 3.7\end{array}$ & $\begin{array}{l}0.7 \\
\pm 0.61\end{array}$ & $\begin{array}{l}10.5 \\
\pm 7.57\end{array}$ & $\begin{array}{l}5.9 \\
\pm 1.9\end{array}$ & $\begin{array}{l}4.8 \\
\pm 1.2\end{array}$ & $\begin{array}{l}21.9 \\
\pm 5.4\end{array}$ & $\begin{array}{l}3.3 \\
\pm 3.7\end{array}$ & $\begin{array}{l}3.6 \\
\pm 3.3\end{array}$ \\
\hline Sand Filter & $\begin{array}{l}8.6 \\
\pm 3.6\end{array}$ & $\begin{array}{l}0.3 \\
\pm 0.40\end{array}$ & $\begin{array}{l}7.5 \\
\pm 5.00\end{array}$ & $\begin{array}{l}1.6 \\
\pm 1.2\end{array}$ & $\begin{array}{l}1.4 \\
\pm 0.66\end{array}$ & $\begin{array}{l}21.3 \\
\pm 0.50\end{array}$ & $\begin{array}{l}3.1 \\
\pm 3.7 \\
\end{array}$ & $\begin{array}{l}2.9 \\
\pm 1.3\end{array}$ \\
\hline$\overline{\mathrm{UV}}$ & $\begin{array}{l}8.3 \\
\pm 3.4\end{array}$ & $\begin{array}{l}0.3 \\
\pm 0.39 \\
\end{array}$ & $\begin{array}{l}6.7 \\
\pm 4.00 \\
\end{array}$ & $\begin{array}{l}1.6 \\
\pm 0.66 \\
\end{array}$ & $\begin{array}{l}1.7 \\
\pm 0.52 \\
\end{array}$ & $\begin{array}{l}18.9 \\
\pm 2.0 \\
\end{array}$ & $\begin{array}{l}3.2 \\
\pm 3.8 \\
\end{array}$ & $\begin{array}{l}1.3 \\
\pm 1.3 \\
\end{array}$ \\
\hline $\begin{array}{l}\text { Pearson } \\
\text { correlation } \\
\text { coefficient } \\
\text { (p-value) } \\
\text { with ARG } \\
\text { concen- } \\
\text { trations }\end{array}$ & $\begin{array}{l}-0.92 \\
(\mathrm{p}<0.05)\end{array}$ & $\begin{array}{l}0.69 \\
(p>0.05)\end{array}$ & $\begin{array}{l}0.65 \\
(p>0.05)\end{array}$ & $\begin{array}{l}0.60 \\
(p>0.05)\end{array}$ & $\begin{array}{l}0.60 \\
(p>0.05)\end{array}$ & $\begin{array}{l}0.62 \\
(p>0.05)\end{array}$ & $\begin{array}{l}0.57 \\
(p>0.05)\end{array}$ & $0.95(\mathrm{p}<0.05)$ \\
\hline
\end{tabular}


Table 2. BNR plant water quality data and Pearson correlation coefficients (average results \pm standard deviations from two sampling events).

\begin{tabular}{|c|c|c|c|c|c|c|c|}
\hline & $\begin{array}{l}\text { Ammonia } \\
(\mathrm{mg} / \mathrm{L})\end{array}$ & $\begin{array}{l}\text { TN } \\
(\mathrm{mg} / \mathrm{L})\end{array}$ & $\begin{array}{l}\text { TSS } \\
(\mathrm{mg} / \mathrm{L})\end{array}$ & $\begin{array}{l}\text { VSS } \\
(\mathrm{mg} / \mathrm{L})\end{array}$ & $\begin{array}{l}\text { COD } \\
(\mathrm{mg} / \mathrm{L})\end{array}$ & TP (mg/L) & $\begin{array}{l}\mathrm{CBOD}_{5} \\
(\mathrm{mg} / \mathrm{L})\end{array}$ \\
\hline Raw influent & $\begin{array}{l}26.2 \\
\pm 6.22\end{array}$ & $\begin{array}{l}39.4 \\
\pm 13.3\end{array}$ & $\begin{array}{l}309.5 \\
\pm 16.3\end{array}$ & $\begin{array}{l}215.15 \\
\pm 5.44\end{array}$ & $\begin{array}{l}607.0 \\
\pm 504.87\end{array}$ & $\begin{array}{l}31.6 \\
\pm 25.7\end{array}$ & $\begin{array}{l}302.3 \\
\pm 215.00\end{array}$ \\
\hline $\begin{array}{l}\text { Primary } \\
\text { Clarifier }\end{array}$ & $\begin{array}{l}14.7 \\
\pm 2.40\end{array}$ & $\begin{array}{l}24.7 \\
\pm 2.92\end{array}$ & $\begin{array}{l}70.8 \\
\pm 35.6\end{array}$ & $\begin{array}{l}55.5 \\
\pm 29.00\end{array}$ & $\begin{array}{l}327.3 \\
\pm 228.16\end{array}$ & $\begin{array}{l}15.4 \\
\pm 2.07\end{array}$ & $\begin{array}{l}225.8 \\
\pm 2.37\end{array}$ \\
\hline BNR & $\begin{array}{l}0.66 \\
\pm 0.39 \\
\end{array}$ & $\begin{array}{l}250.5 \\
\pm 126.6\end{array}$ & $\begin{array}{l}3201.5 \\
\pm 1839.2 \\
\end{array}$ & $\begin{array}{l}1933.8 \\
\pm 690.5\end{array}$ & $\begin{array}{l}1369.5 \\
\pm 976.5 \\
\end{array}$ & $>186.0$ & $\begin{array}{l}462.3 \\
\pm 81.3 \\
\end{array}$ \\
\hline $\begin{array}{l}\text { Secondary } \\
\text { Clarifier }\end{array}$ & $\begin{array}{l}0.11 \\
\pm 0.10\end{array}$ & $\begin{array}{l}3.6 \\
\pm 0.57\end{array}$ & $\begin{array}{l}3.3 \\
\pm 1.27\end{array}$ & $\begin{array}{l}4.3 \\
\pm 2.97\end{array}$ & $\begin{array}{l}40.0 \\
\pm 11.3\end{array}$ & $\begin{array}{l}0.10 \\
\pm 0.07\end{array}$ & $\begin{array}{l}6.5 \\
\pm 4.16\end{array}$ \\
\hline UV & $\begin{array}{l}0.14 \\
\pm 0.15\end{array}$ & $\begin{array}{l}4.0 \\
\pm 0.57\end{array}$ & $\begin{array}{l}3.4 \\
\pm 1.70\end{array}$ & $\begin{array}{l}1.6 \\
0.85\end{array}$ & $\begin{array}{l}18.0 \\
\pm 2.83\end{array}$ & $\begin{array}{l}0.00 \\
\pm 0.00\end{array}$ & $\begin{array}{l}5.6 \\
3.45\end{array}$ \\
\hline $\begin{array}{l}\text { Pearson } \\
\text { correlation } \\
\text { coefficient (p- } \\
\text { value) with } \\
\text { ARG } \\
\text { concentrations }\end{array}$ & $\begin{array}{l}0.83 \\
(p>0.05)\end{array}$ & $\begin{array}{l}0.002 \\
(\mathrm{p}>0.05)\end{array}$ & $\begin{array}{l}0.005 \\
(p>0.05)\end{array}$ & $\begin{array}{l}-0.0001 \\
(p>0.05)\end{array}$ & $\begin{array}{l}0.32 \\
(\mathrm{p}>0.05)\end{array}$ & $\begin{array}{l}0.0035 \\
(p>0.05)\end{array}$ & $\begin{array}{l}0.34 \\
(p>0.05)\end{array}$ \\
\hline
\end{tabular}


Figure 1

Click here to download Figure: Figure 1.docx

A) AL plant

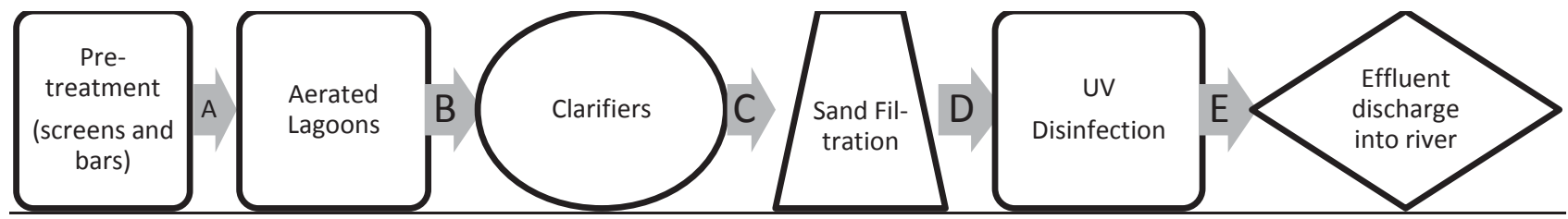

B) BNR plant

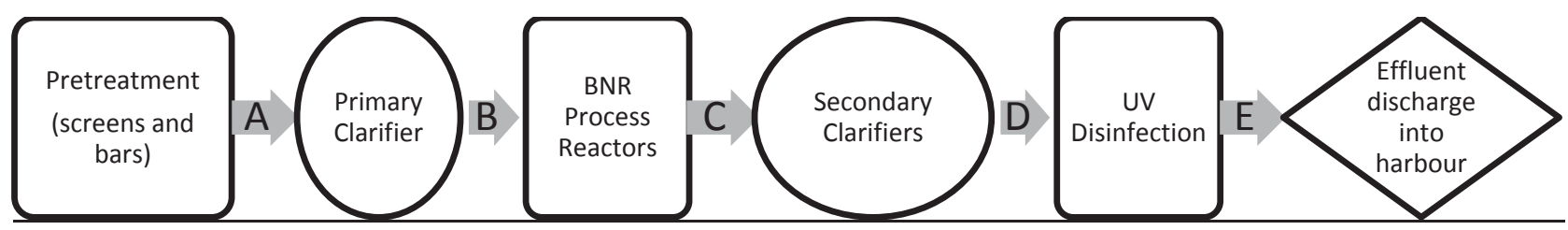

Figure 1. Schematic layout of the treatment trains of A) the aerated lagoon (AL) plant and B) the biological nutrient removal (BNR) plant with sampling sites indicated by letters (A-E). 
Figure 2

Click here to download high resolution image
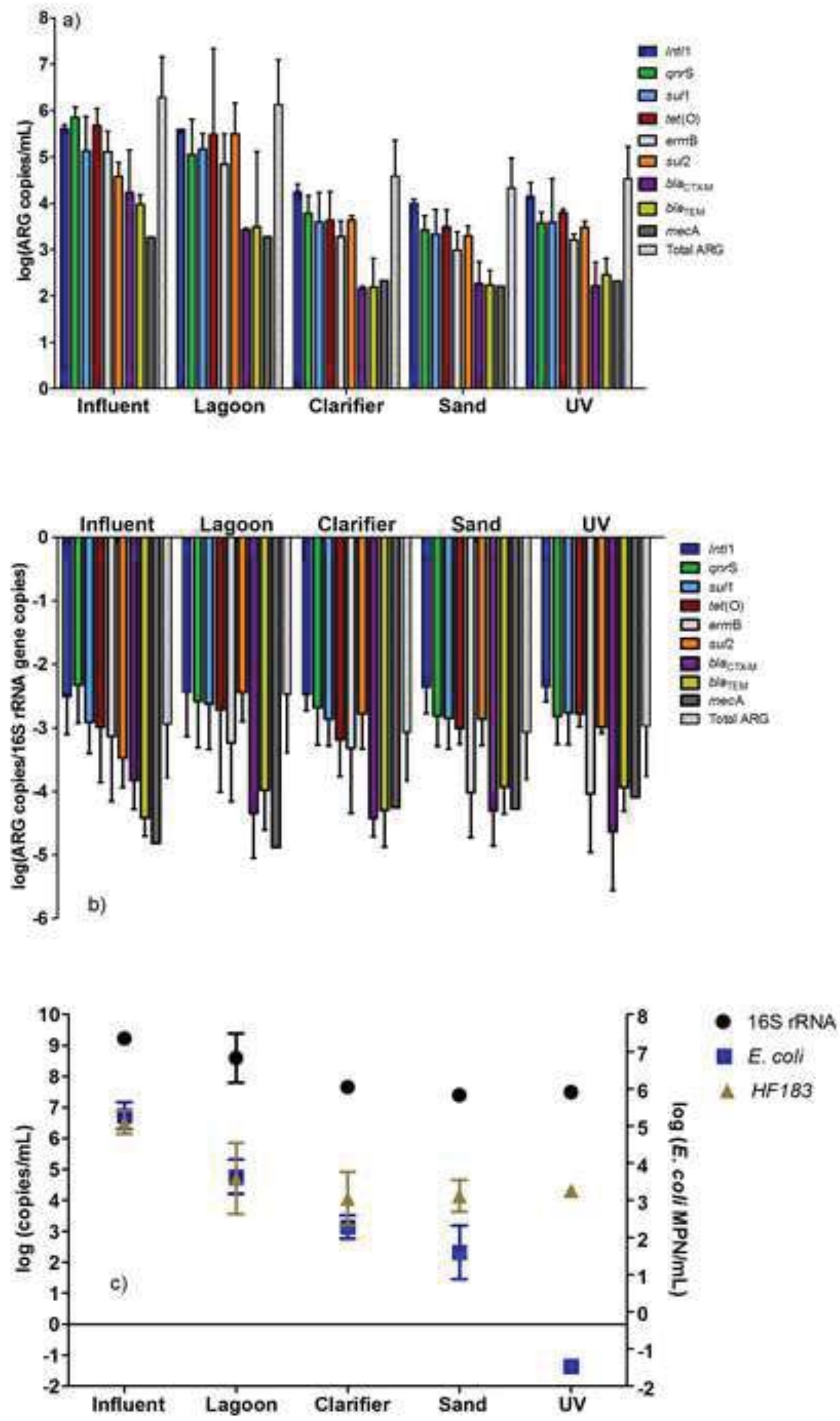
Figure 3

Click here to download high resolution image
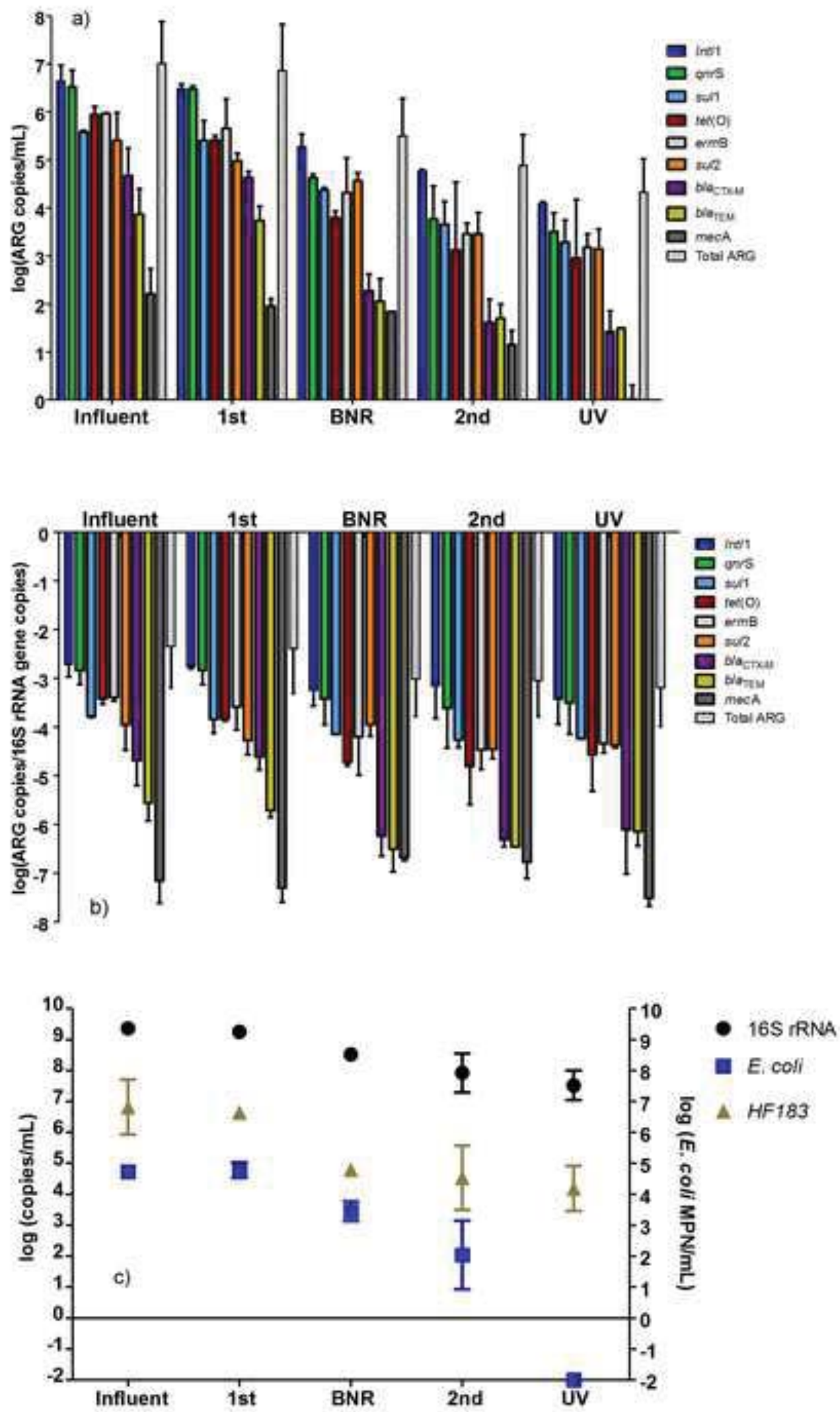
